\title{
Od parowozu do lukstorpedy. Spawanie gazowe w naprawach taboru kolejowego, część I (z teki Jacka Lassocińskiego)
}

\section{From the steam engine to the lux-torpedoes. Gas welding in the repair of railway rolling stock, part I (from Jacek Lassociński's portfolio)}

\section{Streszczenie}

W artykule przedstawiono historię budowy lokomotyw i wagonów do 1939 roku oraz sposoby napraw i regeneracji elementów taboru wykonanych z miedzi metodą spawania acetylenowo-tlenowego.

\section{Abstract}

The history of construction of steam locomotives and cars to the 1939 and the way of repair and regeneration of rolling stock elements made of copper using oxy-acetylene gas welding are presented in the paper.

\section{Początki kolei}

Wiek XIX przyjęto nazywać wiekiem pary i elektryczności. Rozważając jednak wpływ, jaki na przekształcenie stosunków gospodarczych i kulturalnych świata miały wielkie wynalazki, można by go nazwać wiekiem parowozu [1].

Do 1825 r. na całym świecie dominowała komunikacja kołowa konna. Rydwany kołowe znane były już Egipcjanom i Asyryjczykom, jednak w średniowieczu komunikacja lądowa cofnęła się do siodła i juku, by powrócić w epoce Odrodzenia. Pierwszą karetę zbudowano w Anglii w 1568 r. dla królowej Elżbiety. W 1625 r. pojawiła się w Londynie pierwsza dorożka, a w 1659 r. pierwszy dyliżans. Dyliżans ten, z małymi udoskonaleniami, przetrwał do XIX w. [1].

Od czasu, gdy Watt w 1782 r. wynalazł maszynę parową, trwały ciągłe prace nad wykorzystaniem pary jako siły pociągowej.

Pierwszy parowóz do jazdy po szynach został zbudowany w 1803 r. przez Anglika Ryszarda Trevithicka [3]. Parowóz ten, o wadze 4,5 t, był wyposażony w kocioł o średnicy 1,29 m i długości 1,83 m (rys. 1). Jedyny poziomy cylinder o średnicy $210 \mathrm{~mm}$ i skoku tłoka

Dr inż. Anna Pocica - Politechnika Opolska.

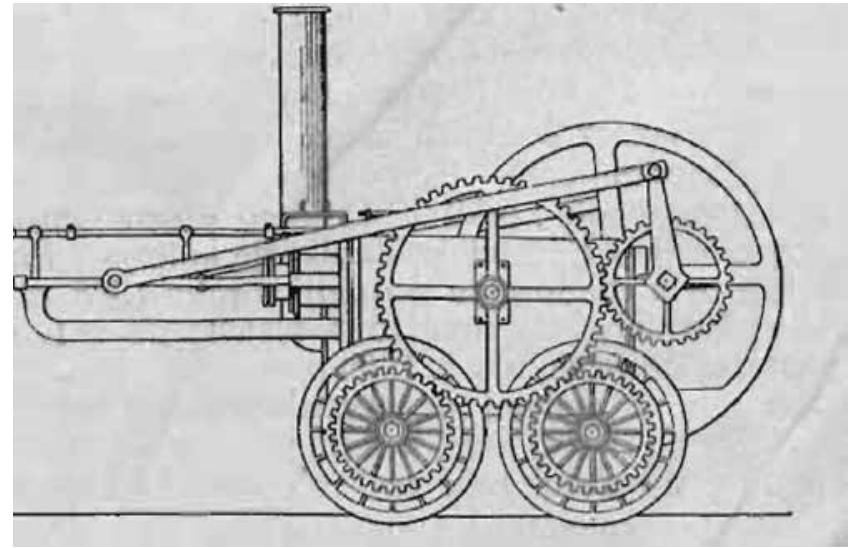

Rys. 1. Pierwszy parowóz do jazdy po szynach zbudowany przez Trevithicka [3]

Fig. 1. First steam locomotive to run on rails built by Trevithick [3]

$1370 \mathrm{~mm}$ napędzał przez przekładnię zębatą z kołem zamachowym dwie pary kół napędowych [3].

Parowóz o całkowicie odmiennej konstrukcji opracował w 1811 r. John Blenkinsop. Parowóz ten miał dwa pionowe cylindry wbudowane w kocioł, poruszał się za pomocą koła zębatego i zębatki ułożonej na szynach. Parowóz ważył $5 \mathrm{t}$ i ciągnął pociąg o ciężarze $15 \mathrm{t}$ na wzniesienie $1: 15 \mathrm{z}$ prędkością $5 \mathrm{~km} / \mathrm{h}[2,3]$.

Dwa lata później William Brunton przedstawił, zupełnie nieudany, pomysł parowozu z mechanizmem 

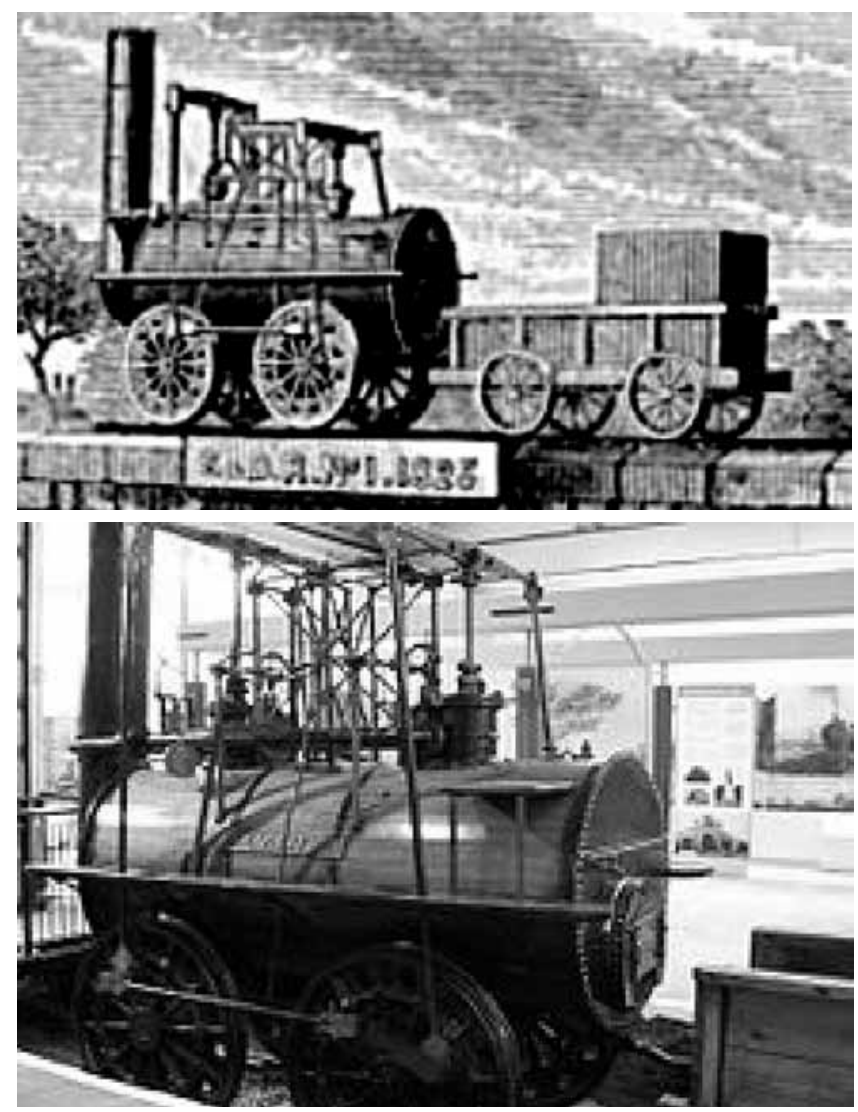

Rys. 2. Parowóz Stephensona z 1825 r. Locomotion No 1 [3] Fig. 2. Stephenson's steam locomotive from 1025 called Locomotion No 1 [3]

napędowym naśladującym chód konia. Bardzo udana natomiast była konstrukcja zaproponowana przez Williama Hedleya. Jego parowóz Puffing Billy pracował w kopalni węgla od 1813 do 1862 r. [3].

W tym samym czasie co Hedley rozpoczął swoje prace „ojciec kolei” George Stephenson. Od 1814 r., w którym skonstruował pierwszy parowóz Bluecher, do 1825 r. (roku otwarcia pierwszej linii kolejowej) pracowało już 16 parowozów Stephensona [3].

W 1825 r. ukończono budowę linii kolejowej pomiędzy miastami Stockton i Darlington w Anglii i 27 września tego roku, specjalnie skonstruowany na tę

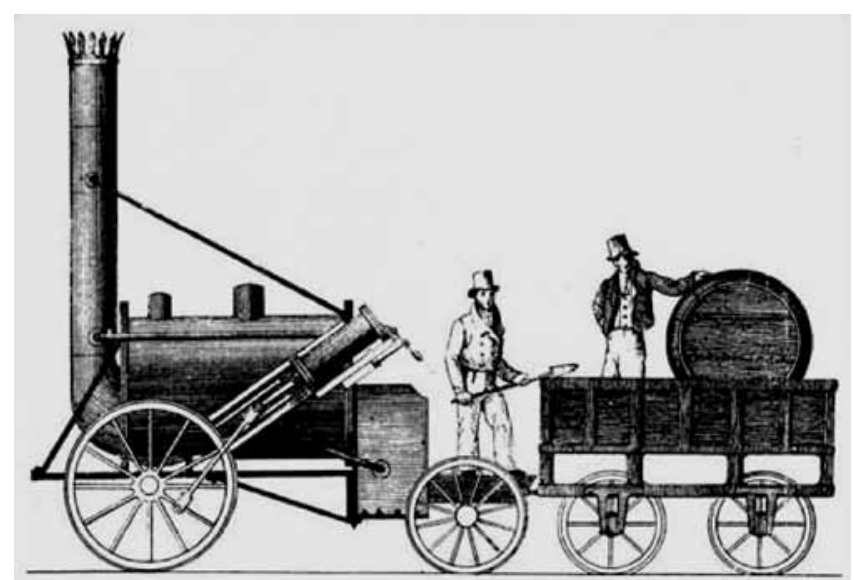

Rys. 3. Parowóz Rockett z 1892 r. [3]

Fig. 3. Rockett steam locomotive from 1892 [3]
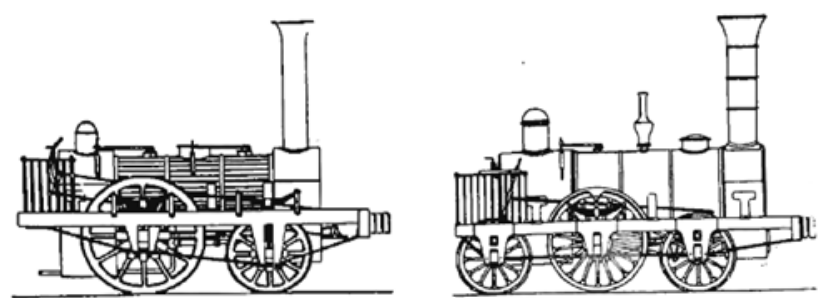

Rys. 4. Parowóz angielski z poziomymi cylindrami [2]

Fig. 4. English steam locomotive with horizontal cylinders [2]

okazję, parowóz Locomotion No 1 wjechał na szyny (rys. 2) [2, 3].

Stephenson ciągle modernizował konstrukcję parowozów. W 1829 r. przedstawił lokomotywę Rockett, w której po raz pierwszy zastosowano kocioł płomieniówkowy w połączeniu ze skrzynią ogniową (rys. 3) [2].

Lata trzydzieste XIX w. to okres nieustannego doskonalenia mechanizmu silnika i jego stawidła, rozwoju formy i tworzenia nowych typów parowozów. Cylindry wbudowywane pionowo w kocioł zastąpiono cylindrami poziomymi, a tłoki przenosiły pracę na wał wykorbiony (rys. 4) [2].

Po ulepszaniu rozrządu pary poprzez rozmaite rozwiązania stawideł jarzmowych zaczęto modernizować konstrukcję podwozia. Wprowadzono wózek zwrotny, jako podparcie przodu parowozu, a także urządzenia ułatwiające przejazd krzywizn za pomocą osi luźnych.

Kolejną innowacją było zastosowanie przez inż. Malleta w 1876 r. dwucylindrowego parowozu z dwustopniowym rozprężeniem pary. Z czasem powstały układy czterocylindrowe sprzężone, co było związane z rosnącym ciężarem parowozów i wymogiem większej prędkości pociągów [2].

Rozwój parowozów na przełomie XIX i XX w. był związany $z$ wynalezieniem przez W. Schmidta w 1897 r. przegrzewacza pary i zastąpieniem pary nasyconej, wytwarzanej $w$ kotłach, parą przegrzaną. Pozwoliło to na zwiększenie sprawności parowozu przez udoskonalenie spalania oraz wykorzystanie ciepła gazów i pary wylotowej [2].

Z czasem maszyny parowe tłokowe zastąpiono turbinami parowymi, a także silnikami spalinowymi z przekładnią mechaniczną, hydrauliczną lub elektryczną do kół napędowych [4].

Z rozwojem parowozu związana jest historia wagonu kolejowego. Pierwsze wagony były to pudła drewniane na 4 kołach, również drewnianych, w postaci tarcz z odpowiednimi wgłębieniami na obwodzie. Ciągnięte były przez konie po drewnianych belkach i stosowano je w angielskich kopalniach i kamieniołomach już w pierwszej połowie XV w. Długość wagonu wynosiła $6 \mathrm{~m}$, a ładowność do $3 \mathrm{t}$ [6].

W wieku XVII belki drewniane, tworzące tory, zastąpiono płytami ze stali, a potem prętami żeliwnymi. W 1754 r. w miejsce kół drewnianych zastosowano koła żeliwne [3]. W XIX w. kolejki konne stosowano również do przewozu ludzi. 
Datą przełomową w historii wagonu było otwarcie linii kolejowej w 1825 r. Od samego początku kolei wagony osobowe dzieliły się na 3 klasy. Wagony trzeciej klasy niewiele różniły się od wagonów towarowych. Były to odkryte pudła i tylko niektóre z nich miały ławki do siedzenia (rys. 5).

Druga klasa była zamykana i wyposażona w wygodniejsze siedzenia. Wagony pierwszej klasy były jednoprzedziałowe, zbudowane na wzór karety (rys. 6) [6].

Wraz z rozwojem kolei zaczęto różnicować konstrukcję wagonów, jednocześnie zwiększając ich

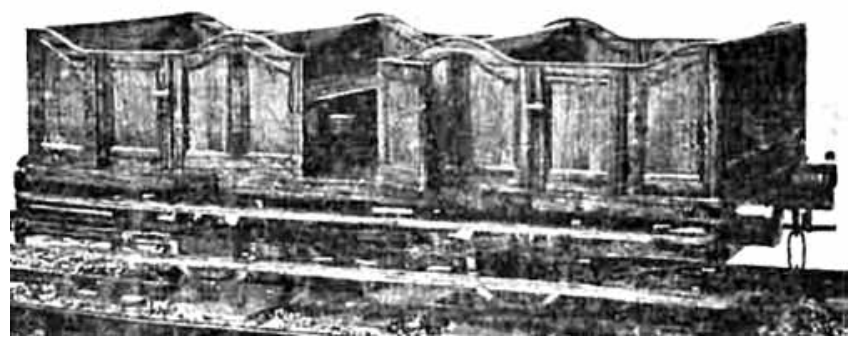

Rys. 5. Angielski wagon osobowy trzeciej klasy z 1840 r. [6]

Fig. 5. English third class passenger car from 1840 [6]

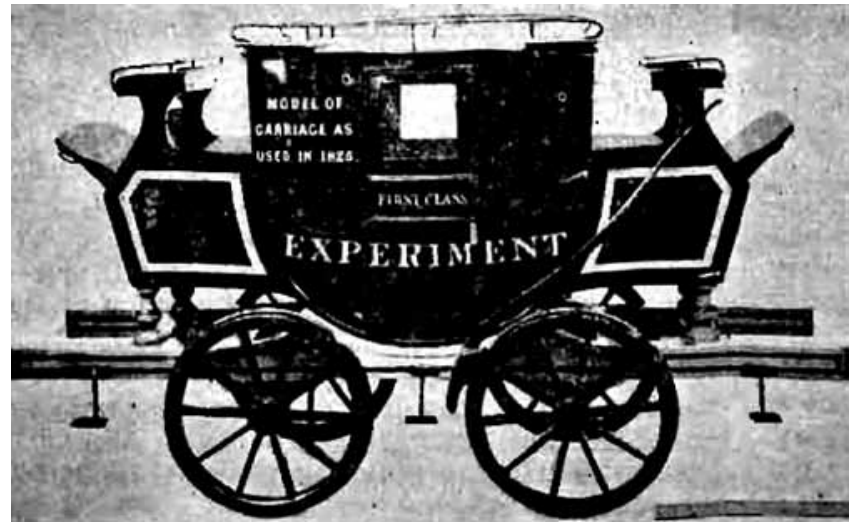

Rys. 6. Wagon osobowy I klasy z roku 1825 [6]

Fig. 6. First class passenger car from 1825 [6]
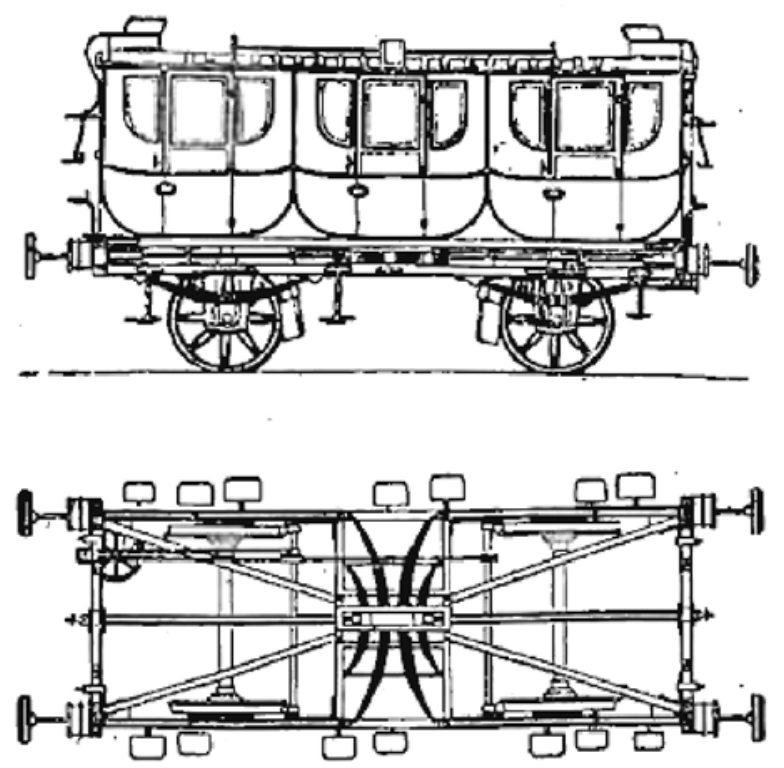

Rys. 7. Wagon osobowy z trzema przedziałami z 1830 r. [6]

Fig. 7. Passenger car with three passenger compartment from 1830 [6] ładowność. Zamiast wagonu jednoprzedziałowego budowano wagony o trzech przedziałach, na wspólnym podwoziu (rys. 7) [6]. W celu zwiększenia komfortu jazdy zastosowano resory, a pod zderzak montowano sprężyste podkładki.

Wagony amerykańskie początkowo przypominały wagony angielskie, jednak od 1835 r. zaczęto produkować długie wagony o jednym przedziale z ławkami w poprzek i przejściem pośrodku, o dwóch wejściach na ścianach czołowych, wagony sypialne i komfortowe wagony tzw. pulmanowskie, wreszcie wagony piętrowe (od 1838 r.). Górne piętro wagonów było przeznaczone dla kobiet i dzieci, dolne dla mężczyzn. Wagony piętrowe zaczęto również stosować w Europie, głównie we Francji, Szwajcarii, Austrii i Niemczech [6].

W latach $1840 \div 1870$ wprowadzano zmiany zwiększające komfort podróży: zainstalowano ogrzewanie, początkowo piecami, a następnie powietrzem lub parą, umieszczono w wagonach oświetlenie naftowe, a potem gazowe, a także umywalnie i toalety [8].

Większość wagonów produkowanych w tym okresie miało podwozie i pudła całkowicie drewniane, choć zdarzały się wagony z ramą stalową. Konieczność zmniejszenia wagi wagonów w stosunku do ich ładowności spowodowała zastąpienie drewna stalą. Od 1847 r. w Ameryce wagony zaczęto budować całkowicie ze stali $[7,8]$, co w przyszłości pozwoliło na zastosowanie w procesie produkcji wagonów spawania zamiast nitowania elementów. Zdecydowanie zmniejszyło to masę konstrukcji, wpływając na zmniejszenie ilości paliwa i zwiększenie prędkości pociągów [8].

\section{Tabor kolejowy w Polsce}

Po odzyskaniu niepodległości Polska odziedziczyła po zaborcach zniszczony przez wojnę tabor i zrujnowane fabryki. W chwili powstania niepodległego państwa nie było na ziemiach polskich ani jednej fabryki lokomotyw i tylko dwie fabryki wagonów [8, 15].

Początkowo więc rozpoczęto remonty zniszczonego taboru, produkcję własnych wagonów i lokomotyw przesuwając do momentu opracowania pełnej dokumentacji technicznej, gdyż ta zaginęła w czasie wojny [8].

Do grudnia 1925 r. po polskich torach jeździło 115 typów lokomotyw, przy czym ponad 3,5 tysiąca z nich miało ponad 10 lat [9].

Na konferencji w 1919 r. ustalono, że do ruchu osobowego potrzebne są trzy typy parowozów: pospieszny, zwykły osobowy i tendrzak (tender to połączony na stałe z parowozem pojazd wyposażony w pomieszczenia na paliwo) do ruchu osobowego podmiejskiego, a do ruchu towarowego: ciężki i bardzo silny do przewozów masowych, Iżejszy do pociągów towarowych pospiesznych oraz przetokowy [9]. Za najpilniejszy uznano zwykły parowóz osobowy i towarowy ciężki. Dzięki temu powstały polskie parowozy $\operatorname{Ty} 23, \operatorname{Tr} 12$, Tr 21 (rys. $8 a \div$ c) $[9,10,14]$. 
a)

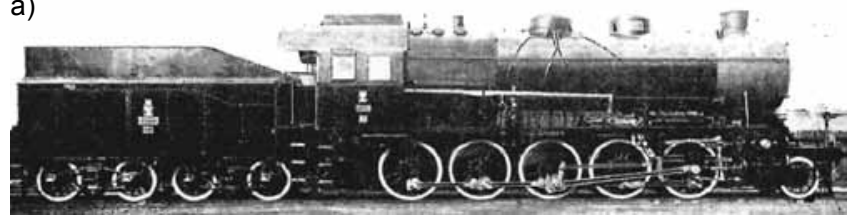

b)

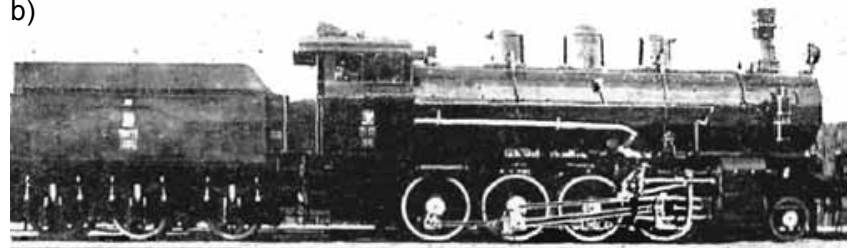

c)

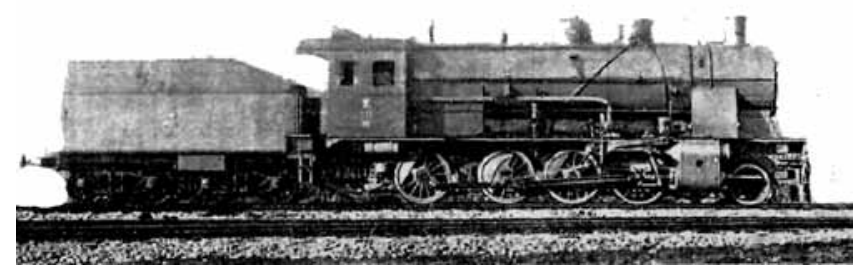

Rys. 8. Parowozy towarowe serii: a) Ty 23; b) $\operatorname{Tr} 12$; c) $\operatorname{Tr} 21$ [9]

Fig. 8. Goods steam locomotives series: a) Ty 23; b) $\operatorname{Tr} 12$; c) $\operatorname{Tr} 21$ [9]

Pierwsza fabryka - Fabryka Lokomotyw w Polsce, zwana powszechnie FABLOK, powstała w 1919 r. Rok później podpisano z rządem umowę na dostawę w ciągu 10 lat 1200 lokomotyw, a także zmieniono nazwę na: Pierwsza Fabryka Lokomotyw w Polsce Zakłady w Chrzanowie [11]. Pierwszy parowóz Tr 21 z części austriackich opuścił zakład w marcu 1924 r., następny wyprodukowano już całkowicie z elementów krajowych $[10,11]$. W okresie międzywojennym $w$ fabryce wyprodukowano 621 parowozów normalnotorowych i 75 parowozów wąskotorowych, w tym 41 na eksport [10].

W 1920 r. powstała Warszawska Spółka Akcyjna Budowy Parowozów. Początkowo wykonywała naprawy lokomotyw zniszczonych przez wojnę (ok. 450 szt.), a w 1923 r. rozpoczęto produkcję nowych lokomotyw, w oparciu o części dostarczone z zagranicy. Do 1928 r. zmontowano 60 parowozów serii $\operatorname{Tr} 12$ (rys. 8b) konstrukcji austriackiej i 42 szt. serii Ty 23 (rys. 8a) konstrukcji niemieckiej [10].

Trzeci z zakładów - Fabryka H. Cegielskiego w Poznaniu, specjalizująca się w maszynach rolniczych i produkcji wagonów, rozpoczęła w 1926 r. montaż jednego typu parowozu Ty 23 [9]. Do wybuchu II wojny światowej wyprodukowano w HCP 275 parowozów [14].

$\mathrm{Na}$ terenach zaborów przed I wojną światową wagony wytwarzano w wytwórniach w Sanoku i w Warszawie. Fabrykę w Sanoku uruchomiono w 1896 r., a w 1913 r. została ona przejęta przez „Uprzywilejowane Fabryki Maszyn i Wagonów L. Zieleniewski w Krakowie, Lwowie i Sanoku". Od początku istnienia w fabryce produkowano wagony osobowe, towarowe, cysterny i tendry parowozowe dla kolei austriackich. Druga wytwórnia wagonów „Towarzystwo Przemysłowe Zakładów Mechanicznych Lilpop, Rau i Loewenstein Sp. Akc. w Warszawie" powstała jeszcze wcześniej, bo w 1818 r. Produkcję wagonów dla kolei rosyjskich rozpoczęto w 1878 r. Były to wagony osobowe oraz luksusowe wagony do pociągu cesarskiego [15].

Wojna całkowicie zniszczyła przemysł wagonowy i trzeba go było budować od podstaw. Fabryka Zieleniewskich, jako że była mniej uszkodzona, już w 1919 r. rozpoczęła produkcję. Ze względu na znaczne zapotrzebowanie, konstrukcje pierwszych wagonów oparto na przedwojennych wzorcach austriackich wagonów drewnianych na stalowym podwoziu, a w 1925 r. przystąpiono do opracowania wagonów wykonanych całkowicie ze stali, opierając się na wzorcach niemieckich, francuskich i włoskich [6, 8]. W Sanoku wytwarzano wagony osobowe, pocztowe, towarowe oraz cysterny do przewozu ropy, benzyny, gazu, spirytusu i kwasów [17].

W zakładach Lilpop, Rau i Loewenstein, mocno zniszczonych w czasie wojny, prowadzono początkowo jedynie naprawy wagonów, z czasem przechodząc do produkcji nowych, głównie osobowych wszystkich klas i wagonów sypialnych [15].

W 1921 r. rozpoczęto produkcję wagonów w Zakładach H. Cegielskiego w Poznaniu [12]. Wytwarzano tam wagony towarowe o różnym przeznaczeniu, węglarki, platformy chłodnie, cysterny do transportu kwasów i gazów, następnie od 1928 r. wagony restauracyjne, sypialne i pocztowe [13], a w 1931 r. rozpoczęto budowę wagonów motorowych [14]. Sumarycznie do wybuchu II wojny światowej w HCP wyprodukowano ok. 5750 wagonów towarowych, ok. 300 osobowych i 33 wagony motorowe [14].

Wagony wytwarzano także w Zakładach Ostrowieckich Sp. Akc. w Ostrowcu. Zakłady całkowicie zniszczone w wyniku działań wojennych szybko odbudowano, przy czym odbudowę huty prowadzono równolegle z budową wytwórni wagonów. Już w 1923 r. pierwsze wagony przekazano kolejom i przez kolejne 5 lat wyprodukowano ok. 7000 wagonów. Były to wagony towarowe i taki profil produkcji zachowano do 1939 r. [15].

\section{Spawanie w naprawach i regeneracji taboru kolejowego}

Spawanie w kolejnictwie było stosowane od początku XX w. Po raz pierwszy zastosowano je do łączenia szyn tramwajowych w 1900 r. [18], a niedługo później we Francji wykonano pierwsze połączenie szyn kolejowych [19].

Już w 1905 r. koleje francuskie, w warsztatach kolejowych, wprowadziły spawanie samorodne (gazowe) przy użyciu palników wodorowo-tlenowych, Szybko jednak zastapiono je palnikami acetylenowo-tlenowy$\mathrm{mi}$, ze względu na wyższą temperaturę spalania acetylenu, co pozwalało uzyskać wyższą wydajność spawania, lepsze wtopienie i mniejsze oddziaływanie ciepła na spawany materiał [20,21].

Początkowo spawanie stosowano jedynie do napraw uszkodzonych lub zużytych części parowozowych. W przypadku wykonywania elementów ze stali, staliwa lub żeliwa proces spawania gazowego był 

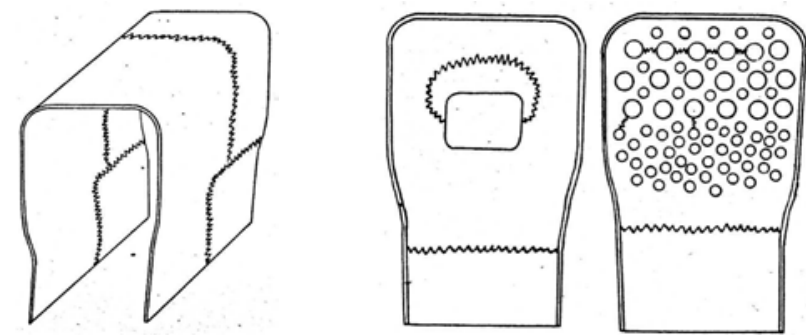

Rys. 9. Przykłady napraw palenisk spawaniem acetylenowym [25] Fig. 9. Examples of furnace repair using acetylene gas welding [25]

stosunkowo prosty i dobrze poznany. Płomień acetylenowo-tlenowy stosowano do napraw stalowych i żeliwnych płomieniówek, elementów przegrzewacza, drzwi dymnicy i drzwiczek paleniskowych, ścian sitowych, ścian paleniska, cięcia blach i materiału ram wózków, a także do regeneracji zużytych powierzchni [20].

Części miedziane, aż do I wojny światowej, uważano za niespawalne [22], jednak występujące w czasie wojny problemy z otrzymaniem miedzi na nowe paleniska parowozów oraz konieczność konserwacji istniejących palenisk spowodowały, że rozpoczęto próby spawania miedzi i z czasem osiągnięto zadowalające rezultaty $[22,23]$.

Do spawania stosowano wytwornice acetylenu lub baterie butli, przy czym wymagano wówczas, by wydajność jednej butli wynosiła $1 \mathrm{~m}^{3} / \mathrm{h}$. W celu odtlenienia pokrywano spoiny warstwą rozżarzonego węgla drzewnego [22] albo pastą lub proszkiem zawierającym do 0,5\% związków fosforu [24]. Aby uniknąć przegrzania materiału, przy większych przekrojach stosowano dwa palniki - jeden służył do podgrzewa-

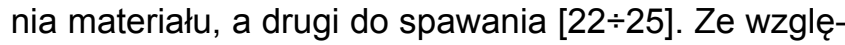
du na wysokie przewodnictwo cieplne miedzi, palnik do nagrzewania miał wydajność $2800 \mathrm{l} / \mathrm{h}$, a palnik do spawania $1800 \div 2000 \mathrm{l} / \mathrm{h}$ [25]. Spoiny co $120 \div 150 \mathrm{~mm}$ przekuwano młotkiem, co zapobiegało porowatości spoiny i zmniejszało jej skurcz [27, 28]. Materiałem dodatkowym był na ogół drut Canzler zawierający $98,98 \% \mathrm{Cu}$, ok. $1 \% \mathrm{Ag}, 0,01 \% \mathrm{P}, 0,04 \% \mathrm{Ni}[22]$ (inni autorzy podają zawartość srebra ok. 5\% [24]). Stosowano również drut elektrolityczny, bez fosforu

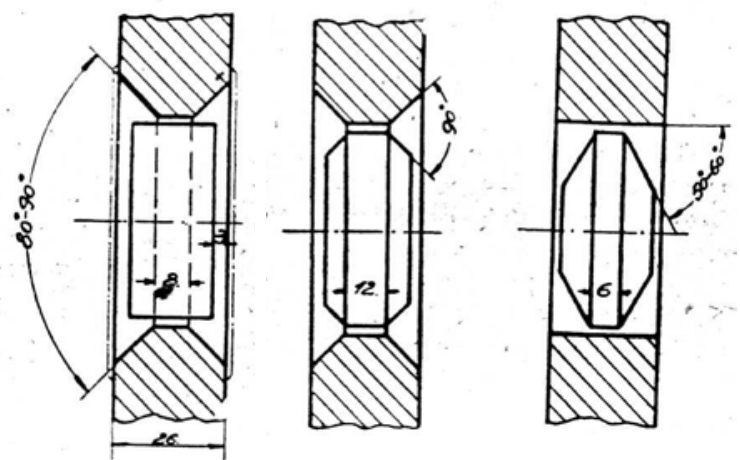

Rys. 10. Krążki miedziane stosowane przy naprawie ścian sitowych [22]

Fig. 10. Copper rings used for perforated bottom repair [22] i z mniejszą ilością srebra [22]. Badania mechaniczne obu rodzajów drutu wykazały, że spoiny wykonane drutem elektrolitycznym mają mniejszą wytrzymałość i plastyczność [27]. Najlepszy do spawania miedzi był drut specjalny zawierający $98,7 \% \mathrm{Cu}, 2 \% \mathrm{Ag}$ oraz do 0,2\% P [25].

Spawanie stosowano głównie do napraw bieżących palenisk, w tym do napawania opalonych brzegów blach, pęknięć różnego rodzaju, naprawy mostków i otworów w ścianie sitowej oraz napraw głównych, tj. wstawiania łat oraz falban (łat na całej długości

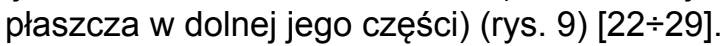

W praktyce najpoważniejsza była naprawa ścian sitowych. W wyniku wymiany płomieniówek następowało rozszerzanie otworów i ich owalizacja, a także pękanie tzw. mostków. Naprawa polegała na napawaniu otworów i następnie ich rozwierceniu [29]. Stosowano również krążki miedziane, o różnym kształcie, wstawiane w zniekształcone otwory (rys. 10) [22].

W pierwszym przypadku frezowano krawędzie otworu wstawiono krążek cylindryczny, w drugim zarówno krawędzie krążka, jak i otworu były ścięte, a w ostatnim otwór był nieobrabiany, a krążek miał kształt soczewki. Po nagrzaniu materiału do otworu wstawiano dopasowany krążek, do którego był przyspawany drut. Jeden spawacz trzymał drut, stabilizując krążek, a inny spawacz, z drugiej strony, wykonywał spoiny sczepne. Potem drut usuwano i jednocześnie z obu stron spawano. Po spawaniu całość przekuwano, podstawiając płaski młotek $z$ jednej strony i bijąc z drugiej okrągłym [22, 28].

W przypadku pękniętych mostków wycinano rowki z obu stron ściany wzdłuż pęknięcia, następnie w przypadku rur żarowych spawano dwustronnie, a przy pęknięciach między rurami płomiennymi zaspawywano dwa otwory przyległe do pęknięcia, „zalewano” pęknięcie, przekuwano i wiercono na nowo otwory [22].

Wstawianie łat bocznych odbywało się, o ile było to możliwe, w pozycji poziomej, przy czym spawano trzy boki, a czwarty był nitowany [28]. Falbany natomiast spawano w pozycji pionowej, ukosując blachy na $X$, po czym dwóch spawaczy spawało z obu stron jednocześnie. Gdy nie było dostępu z obu stron, ukosowano blachy na $\mathrm{V}$ i przekuwano z jednej strony, podstawiając młot ze strony przeciwnej [29].

O celowości i rentowności spawania kotłów decydowały: pewność naprawy, jej szybkość i koszty [28].

Naprawa palenisk za pomocą spawania dawała $3,4 \%$ wad, podczas gdy nitowanie $20 \%$. Koszty spawania, które nie były niskie, były i tak dużo mniejsze niż koszty nitowania tych samych elementów. Koszt wykonania $1 \mathrm{~m}$ bieżącego połączenia nitowanego wynosił 233 zł, a połączenia spawanego 188 zł, czyli spawanie było o $19 \%$ tańsze. Przy $25 \%$ ścian paleniska podlegających naprawie (co często występowało w praktyce) koszty naprawy spawaniem były aż o $42 \%$ niższe niż przy nitowaniu [27].

Spawanie acetylenowo-tlenowe miedzi zaczęto stosować w Polsce dość późno, bo dopiero w 1922 r. 
Wcześniejsze próby, prowadzone w 1920 r. w Bydgoszczy, nie dawały gwarancji uzyskania prawidłowego połączenia [29]. Na szerszą skalę rozpoczęto spawanie miedzianych skrzyń w Warsztatach Kolejowych we Lwowie [28] i w Nowym Sączu [29]. Na początku sprowadzono z Niemiec materiały dodatkowe i dwóch spawaczy, którzy prawie przez rok uczyli polskich robotników. Z czasem zastąpiono importowany drut niemiecki Canzler dużo tańszym drutem polskim, produkowanym przez hutę miedzi i sprzedawanym przez Francuskie Towarzystwo Perun [29]. O wysokim poziomie osiągniętym przez polskich spawaczy świadczy spawanie uszkodzonych palenisk o grubości ściany 25 mm - wyczyn nie lada w ówczesnym czasie [30].

\section{Literatura}

[1] J.E.: Stulecie kolei. Przegląd Techniczny 1926, nr 1-2, s. 1

[2] Mozer W.: Krótki rys historyczny rozwoju lokomotyw. Od Stephensona do czasów obecnych. Przegląd Techniczny 1926, nr 3, s. 21-25.

[3] Odlanicki-Poczobut M.: Od Trewithicka do Stephensona (szkic dziejów parowozu). Przegląd Techniczny 1926, nr 1-2, s. 2-5.

[4] Odlanicki-Poczobut M.: Postępy w budowie parowozów turbinowych. Przegląd Techniczny 1928, nr 2, s. 35-41.

[5] Odlanicki-Poczobut M.: Budowa parowozów w roku 1927. Przegląd Techniczny 1928, nr 4, s. 81-82.

[6] Małkiewicz P.: Rys historyczny rozwoju wagonów kolejowych. Przegląd Techniczny 1926, nr 1-2, s. 6-10

[7] Małkiewicz P.: Budowa wagonów w ciągu ostatnich lat. Przegląd Techniczny 1928, nr 4, s. 80-81.

[8] Małkiewicz P.: Postępy w budowie wagonów. Przegląd Techniczny 1933 , nr 10 , s. 265-271.

[9] Dąbrowski J.P.: Budowa parowozów w Polsce. Przegląd Techniczny 1929, nr 4-5, s. 85-89.

[10] Piwoński J.: Parowozy kolei polskich. WKik, Warszawa 1978, s. 23-33.

[11] Pokropiński B.: Parowozy normalnotorowe produkcji polskiej. WKiŁ, Warszawa 2007, s. 9-10.

[12] Sołtysiński B., Jaworski B.: Historia HCP - 125 lat. Biuletyn techniczny 1971, nr 1, s. 37.

[13] Ogłoszenie reklamowe firmy H. Cegielski Sp. Akc. Przegląd Techniczny 1934, nr 13, s. 109.

[14] Tatara F.: Budowa wagonów w Zakładach H. Cegielski. Biuletyn Techniczny 1959, nr 7-8, s. 57-67.

[15] Jabłoński I.: Polski przemysł wagonowy. Przegląd Techniczny 1929 , nr 4-5, s. 89-96.

[16] Spawanie i Cięcie Metali. 1932, nr 5-6, s. 81-82.

[17] Dydek S.: Od kotła do samochodów i przyczep. Praca zbiorowa pod red. A. Orłowskiego. WLS, Warszawa 1982, s. 15.

[18] Spawanie szyn termitem. Przegląd Techniczny 1933, nr 10 , s. $283-284$.

[19] Andrzejewski S.: Zastosowanie spawania w celu wydłużenia szyn oraz przy wyrobie i utrzymaniu rozjazdów. Inżynier Kolejowy 1927, nr 3, s. 360-363.

[20] Gayczak T.: O sposobach spawania stosowanych w warsztatach kolejowych francuskich. Mechanik 1923, z. XV, s. $153-158$.

[21] Strausfogel I.: Warsztaty kolejowe i praktyka warsztatowa. Drukarnia Państwowa, Warszawa 1925, s. 59-63.

[22] Bieliński A.: Spawanie miedzi w kolejnictwie. Inżynier Kolejowy 1939 , nr 4, s. 136.

[23] Czaykowski S.: Naprawa żelaznych palenisk kotłów parowozowych za pomocą spawania. Spawanie i Cięcie Metali 1929, nr 6, s. 90-94.

[24] Czaykowski S.: Naprawa ścian miedzianych palenisk parowozów za pomocą spawania acetylenowo-tlenowego. Spawanie i Cięcie Metali 1929, nr 9, s. 3-8.

[25] Lisowski W.: Zastosowanie spawania acetylenowego do naprawy miedzianych palenisk kotłów parowozowych. Spawanie i Cięcie Metali 1931, nr 8, s. 120-123.

[26] Proczkowski M.: Uszkodzenia kotłów parowozowych i ich naprawa. Czasopismo Techniczne 1923, nr 19, s. 281-285.

[27] Lisowski W.: Zastosowanie autogenicznego spawania do napraw miedzianych palenisk kotłów parowozowych. Inżynier Kolejowy 1932, nr 5, s. 110-115.

[28] Gayczak T.: O naprawie miedzianych skrzyń paleniskowych metodą spawania samorodnego. Mechanik 1924, z. XII, s. $129-131$.

[29] Gabryś J.: Pierwsze zastosowania i rozwój spawania acetylenowego w naprawie palenisk miedzianych kotłów parowozowych. Przegląd Spawalnictwa 1952, nr 10, s. 239-240.

[30] Dobrowolski Z.: Z dziejów spawalnictwa w Polsce. Przegląd Spawalnictwa 1977, nr 3, s. 49-51. 